Relations industrielles

Industrial Relations

\title{
Gösta Esping-Andersen, The Three Worlds of Welfare Capitalism
}

\section{Alexander J. Matejko}

Volume 47, numéro 1, 1992

URI : https://id.erudit.org/iderudit/050759ar

DOI : https://doi.org/10.7202/050759ar

Aller au sommaire du numéro

Éditeur(s)

Département des relations industrielles de l'Université Laval

ISSN

0034-379X (imprimé)

1703-8138 (numérique)

Découvrir la revue

Citer ce compte rendu

Matejko, A. J. (1992). Compte rendu de [Gösta Esping-Andersen, The Three Worlds of Welfare Capitalism]. Relations industrielles / Industrial Relations, 47(1), 178-181. https://doi.org/10.7202/050759ar

Tous droits réservés (C) Département des relations industrielles de l'Université Laval, 1992
Ce document est protégé par la loi sur le droit d'auteur. L'utilisation des services d'Érudit (y compris la reproduction) est assujettie à sa politique d'utilisation que vous pouvez consulter en ligne.

https://apropos.erudit.org/fr/usagers/politique-dutilisation/ 
Any comprehensive analysis of occupations must move beyond the design of work to consider the conditions and experience of work, and this Lockhart does with considerable aplomb. He carefully documents historical changes such as the decline in the market for highly qualified manpower, and the recently imposed higher recruitment standards as factors which may increase teachers' occupational committment. Again a special run of data from the Carleton University Class Structure Project allows comparisons of teachers with hourly wage workers and managerial professional groups, and shows that teachers have both the highest median income and the highest proportion of members at the median income level (p. 68).

The pervasive issue of autonomy and control throughout the literature on professions becomes a special case for teachers. Lockhart concludes that "... teachers do not appear to be exceptionally committed to full professional autonomy" (p. 75). However, he also reports certain contradictions that inhere in the work culture. Whereas teachers "... require and are afforded the freedom to be innovative in the way they approach their classroom work, they are not given commensurate freedom over curricular content and scheduling" (p. 81).

Although teachers' associations beginning in the 1960's moved from a "genteel professionalism to a more militant unionism", bread and buter issues of salary tended to dominate union agendas. Furthermore the point is well taken that strike activity by public service employees is often felt more by clients than employers and can result in damage to the "special trust between worker and community". The ongoing politicization of teachers associations shows evidence of being both confrontational and coalitional. However teachers' efforts to develop a more professionally responsible work environment are constantly encountering a crisis of authority both within and beyond the classroom.

Finally, the tension between collegial versus hierarchical control over the organization and delivery of a knowledge based service is certainly a pervasive issue, as Lockhart points out. However, as this study and others have shown there are some serious impediments in the way of teachers taking more responsibility in shaping the goals and conditions of schooling. Indeed given the press of everyday activities, teachers often have little for critical reflection let alone challenge.

Lockhart has provided all interested stakeholders in Canada's public educational system with an important account of the major issues affecting the teaching profession and education. It should be required reading for them all.

John HARP

Carleton University

The Three Worlds of Welfare Capitalism, by Gösta Esping-Andersen, Princeton, N.J., Princeton University Press, 1990, XI+248 p., ISBN 0-69102857-5

The study done by the author questions the validity of the convergence theory on the basis of empirical test applied to the countries that are different in 
their developmental itineraries and historical backgrounds. Much of statistical and other documentation was collected and analysed in order to search for similarities and dissimilarities of welfare capitalism in each country. Such empirical verification of the convergence theory is particularly valid now, when the market orientation seems to be evidently winning over the state socialist command model. At the same time the new situation arising from the decline of the Soviet style communism should not lead to the denial of some evident differences existing between the leading industrial democracies. The set of circumstances specific for a given country or several countries introduces specific variations of welfare capitalism and the author has managed to verify them.

The comparison of mainly the US, Germany and Sweden, but also of some other developed societies, leads the author to several important conclusions regarding, among others, mutual relationships between labour markets and welfare states. "We are witnessing three divergent paths to post-industrial employment: each country is nested in its own peculiar dynamics and development. There are, to be sure, certain basic parallels: industrial employment is losing its prominence; distributive services are generally stagnant; women's employment chances have improved. Yet, the variations overshadow convergence" (p. 214).

In Germany the traditional industrial society, characterised by the relatively under-developed private and public service sector, remains intact. The recent absorbtion of the GDR has even reinforced that profile. The job distribution is much gender-segregated: German women are over-represented in the 'junk-jobs' (unskilled, lowly paid, unstable). There is much dependence on welfare services in several categories of the population (the young, the elderly, housewives) and this has become recently reinforced by the very high unemployment rate in the eastern territories.

In Sweden the welfare state has been extraordinarily dynamic, especially in absorbing women into the public sector with several positive but also negative consequences (for example, a very high absenteism among the working mothers of small children). "The Swedish employment-structure is evolving towards two economies: one, a heavily male private sector; the other, a female-dominated public sector" (p. 215). It is necessary to mention that the socialist welfare state has become weakened mainly due to the dissatisfaction of the population with high taxation, the bureaucratic nuisance, and the growing surcharge on welfare services (socialists lost parliamentary elections in Sept. 1991).

In the US social services have expanded without public provision, the basic difference with Sweden. Good jobs have clearly outpaced the bad ones but this may not last for long. The US trajectory is "at once overpoweringly biased towards business and towards 'fun' services, giving rise to a duality with large quantities of good and bad jobs. The good jobs are heavily managerial, and the 'junk-job' sector is enormous" (p. 215). Women and racial minorities still are overrepresented in the less desirable jobs but particularly women gradually improve their positions (Hispanics are making less progress than the rest). "The degree of Black and Hispanic over-representation in the 'junk-jobs' is today no greater than it was for women in Germany and Sweden in the 1960s" (p. 215-216). In general, in the US both the good jobs and the "junk-jobs" are becoming 
assigned more democratically; the multiplication of "junk-jobs" depends much on the maintenance of low wages and in this respect services in Germany and even more in Sweden remain handicapped. The growth of Swedish professional and social-welfare jobs depends mostly on taxes from which these services are generously financed.

Welfare states and employment systems coincide. "Welfare states indeed have a direct causal impact on how employment-structures and, as a result, new axes of social conflict, evolve (...). The contemporary welfare state is not merely a passive by-product of industrial development" (p. 221). The difference between the socialist (Sweden), conservative (Germany), and liberal (US) regime-type makes much difference regarding, among others, the modern labour market." Sweden has produced a social-welfare led post-industrial employment structure; the United States, a dual one of business-services and 'fun', with largely good jobs in the former, and bad jobs in the latter; in Germany, nothing much in the way of 'post-industrial' change has happened" (p. 222).

The emphasis on leisure and entertainment is characteristic for all developed societies but in some of them, primarily in North America, there is a growing problem of an adequate balance between services and the actual productive capacity of a given society. For example, the decline of manufacturing is an important source of unemployment. The major growth of public service-employment in Sweden happens on expense of taxpayers, as well as wage restraints. In Germany there is a problem how to finance the growing population of pensioners, unemployed, and non-actives in general $160 \%$ of inactive population in comparison with $49 \%$ in Sweden). Services remain undeveloped and the state hesitates to enter that field directly or even indirectly. The American way is to encourage the market to multiply several such services which in Sweden are available directly from the state. With the fast growth of the service sector there appears an urgent problem of who is actually responsible for it in modern societies and who and how, should promote services.

Social conflicts in the postindustrial era differ in their character depending on the model of the welfare state. In Sweden it is the confrontation between the female dominated public services and male dominated private sector. In Germany it is the difference of interests between the insiders (members of well established unions) and outsiders (women, foreigners, undeveloped services, inactive population). In the US there is a major gap between the performers of 'junk-jobs' and the successful business services. An essentially race- and ethnicity-based dualism of life chances is the fact of life. For example, $67 \%$ of blacks and only $16 \%$ of whites claim that every possible effort, including preferential treatment, should be made in order to improve the position of minorities in the US society. Coloured people and the young locked into the substandard jobs are a problem not only in the US but also in the UK. Among the British 17-year-olds only $35 \%$ are still in full-time study in comparison with over two times more in Germany, US, Japan, and even France.

The book here under review is a valuable contribution to the critique of the convergence theory still much influencing the Western social scientists. Socioeconomic development of societies actually follows divergent patterns originating from the local traditions and conditions, as well as from social consciousness and the type of democracy characteristic for a given society. 
There is no substantial proof that big powers will be able to impose their own socio-economic schemes on other societies, as long as the latter follow successfully their own models. The study done by G. Esping-Andersen reinforces the pluralist option of the socio-economic development.

Alexander J. Matejko

University of Alberta

Comprendre et próvenir le burnout, par Claude Gervais, Montréal, Les éditions Agence d'Arc, 1990, 214 p., ISBN 2-89022-233-0

Le concept de burnout est apparu au début des années 70 . II tire ses origines des travaux de Freudenberger afin de décrire une combinaison de symptômes qui se manifestent notamment par un épuisement chronique, une fatigue physique, une absence d'implication au travail, une déshumanisation des services aux bénéficiaires ainsi qu'une diminution des réalisations au travail. L'ouvrage de Claude Gervais est articulé autour de la prévention du burnout au travail.

L'auteur développe un modèle diagnostic du burnout qui sert de cadre d'analyse dans l'élaboration d'une démarche préventive. Plus particulièrement, une description ponctuelle des causes, du processus, des conséquences du burnout ainsi que des méthodes d'intervention sont présentées et abondamment illustrées à l'aide d'exemples cliniques. Afin de concrétiser l'orientation résolument clinique du livre, des questionnaires d'évaluation sur la vulnérabilité au burnout et des études de cas accompagnent un ensemble de principes à respecter dans l'élaboration d'un programme de relation d'aide à la victime de burnout.

Le plan de travail qui est à l'origine de ce volume reflète bien la préoccupation précitée. La structure du livre s'organise autour de quatre chapitres. L'introduction établit les bases conceptuelles de la notion de burnout. L'auteur conceptualise le burnout comme un processus cumulatif à 6 étapes et intègre la littérature sur le stress au travail dans son modèle. Par ailleurs, il emprunte certains éléments des modèles de Cherniss, Golembiewski, Maslach et Pines. Le burnout est le résultat d'une accumulation de tensions mal canalisées entre l'individu et son emploi et entraînant une impression d'échec, une baisse d'efficacité ainsi qu'une perte d'intérêt notable pour le travail (p. 22). La définition proposée renvoit à la perspective interactionniste développée par French pour le diagnostic des causes du burnout. Selon l'approche interactionniste, le stress au travail survient quand l'environnement de travail exerce des demandes sur l'individu qui ne cadrent pas avec ce que ce dernier peut offrir. Le burnout constitue l'étape finale à une progression de tentatives infructueuses afin de composer avec des conditions de stress au travail. Plus spécifiquement, lorsque la demande du milieu de travail taxe exagérément la capacité d'adaptation de l'individu, ce dernier est susceptible d'être victime de burnout. La relation entre la demande du milieu de travail et le burnout est donc modérée par le stress au travail. L'auteur souligne également que le support social constitue une variable modératrice importante dans cette relation. 